\title{
Recorded Library Use in Small Four-Year Colleges, 1962-1963
}

\author{
BY R. VERNON RITTER
}

As A MEANS of getting a basis of comparison for an evaluation of student and faculty use of small college libraries, a questionnaire was circulated to 151 such libraries asking for relevant figures. In order to make the information useful, the colleges were limited to accredited, fouryear, liberal arts institutions with enrollments ranging from four hundred to seven hundred, as reported in the United States Office of Education, Library Statistics of Colleges and Universities, $1962-$ 63 . Since there is variation in the percentage of full-time students making up college enrollment figures, only the fulltime equivalent (FTE) enrollment figures were used for per capita computations. The questionnaires used were limited further to colleges having FTE enroll-
Mr. Ritter is Librarian of Westmont College, Santa Barbara, California.

recorded use. Eight libraries indicated employing open reserves; in such cases their reserve circulation figures included only overnight circulation of reserves. Because this might materially alter the results these latter figures were not included in the statistics.

Since the FTE number of faculty members was not requested, no per capita faculty circulation figures are available. Usually the size of the faculty correlates very closely with the size of the student body; the total figures therefore may still have some value for comparison with the statistics from one's own campus.

A summary of the statistics follows.

\begin{tabular}{|c|c|c|c|c|c|}
\hline & Enrollment & $\begin{array}{l}\text { Reserve Cire. } \\
\text { Per Cap. }\end{array}$ & $\begin{array}{l}\text { General Circ. } \\
\text { Per Cap. }\end{array}$ & $\begin{array}{l}\text { Total Circ. } \\
\text { Per Cap. }\end{array}$ & $\begin{array}{c}\text { Faculty Cire. } \\
\text { Total }\end{array}$ \\
\hline $\begin{array}{l}\text { High } \\
\text { Low } \\
\text { Median } \\
\text { Mean }\end{array}$ & $\begin{array}{l}669 \\
325 \\
521 \\
516\end{array}$ & $\begin{array}{r}72.0 \\
1.6 \\
11.8 \\
15.9\end{array}$ & $\begin{array}{l}78.8 \\
10.2 \\
28.2 \\
29.4\end{array}$ & $\begin{array}{r}135.4 \\
16.3 \\
42.7 \\
46.1\end{array}$ & $\begin{array}{r}11,985 \\
50 \\
1,467 \\
1,872\end{array}$ \\
\hline
\end{tabular}

ments of 325 to 699 . There were 117 responses to the 151 questionnaires sent out (a few more came too late to be used). Seventeen of these were not usable because of incompleteness or unusual methods of keeping and reporting circulation statistics, and a few were thrown out because enrollments had climbed over 699 FTE.

Only eight libraries reported having closed or partially closed stacks, which of course means that for ninety-two remaining libraries actual use goes beyond
In view of the close correlation of the size of the faculty and the size of the student body, one of the startling things was the lack of correlation between the size of the school and the faculty circulation. Other factors, such as intellectual alertness and research interests, are evidently much more significant than numbers for producing high faculty circulation figures. Seven out of the eleven highest faculty circulation figures were from schools below the median size of student body. Further, the average total faculty circu- 
lation for all schools with student bodies ranging from 521 (the median size) to 699 , was 1,961 . This is only $171(9.6$ per cent) more than for schools with student bodies ranging from 325 to 521 , which was 1,790 , even though faculty size for this latter group must have been nearly double that of the first group.

Another interesting development is the relationship of reserve and general circulation. In 1940 Harvie Branscomb noted that "the average student draws from the general collection of his college or university library about twelve books per year. . . . In addition . . . this undergraduate, on the average, seems to make from fifty to sixty withdrawals per year from the reserve book collection. . . ." The

\footnotetext{
${ }^{1}$ Teaching With Books (Chicago: ALA, 1910), p. 27 .
}

present survey would indicate that average per capita loans from the general collection have more than doubled in the intervening years (and this despite more widespread use of open stacks); at the same time reserve circulation has been cut to about one-fourth of what it was at that time. This shift is no doubt accounted for by less extensive use of reserve shelves as a teaching aid, and more emphasis on a student's initiative in locating sources relevant to his courses. The greatly increased general-collection loans result, therefore, from this shift and compensate for greatly reduced reserve use. In this survey only five libraries had per capita reserve circulation above fifty. Of these, three also had above-average general-collection circulation.

\title{
About Membership
}

\begin{abstract}
ALA MEMBERSHIP is for the calendar year, January to December. Personal dues are based on annual salary; institutional dues on the annual operating income of the library for the previous fiscal year. Every member receives two divisional memberships, a type-of-library division ąnd a type-of-activity division. Type-of-library division might be ACRL, type-of-activity division might be one from a choice of eight. Available back issues of membership publications will reach members who enroll after January. For further details, write: Membership Promotion, ALA Headquarters, 50 East Huron Street, Chicago, 60611 .
\end{abstract}

